\title{
Polymorphisms in the epidermal growth factor receptor gene and the risk of primary lung cancer: a case-control study
} Jin Eun Choi ${ }^{1}$, Sun Ha Park², Kyung Mee Kim², Won Kee Lee, Sin Kam³, Sung Ick Cha ${ }^{4}$, Chang Ho Kim ${ }^{4}$, Young Mo Kang ${ }^{4}$, Young-Chul Kim ${ }^{5}$, Sung Beom Han ${ }^{6}$, Tae Hoon Jung ${ }^{4}$ and Jae Yong Park*1,2,4

\begin{abstract}
Address: ${ }^{1}$ Department of Biochemistry, School of Medicine, Kyungpook National University, Dong In 2Ga 101, Daegu, 700-422, South Korea ${ }^{2}$ Cancer Research Institute, Kyungpook National University Hospital, Samduk 2Ga 50, Daegu, 700-412, South Korea, ${ }^{3}$ Department of Internal Medicine, Kyungpook National University Hospital, Samduk 2Ga 50, Daegu, 700-412, South Korea, ${ }^{4}$ Department of Preventive Medicine, School of Medicine, Kyungpook National University, Dong In 2Ga 101, Daegu, 700-422, South Korea, ${ }^{5}$ Department of Internal Medicine, Chonnam

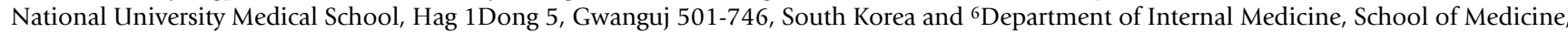
Keimyung University, Dongsan Dong 194, Daegu, 700-712, South Korea

Email: Jin Eun Choi - ddochi74@hanmail.net; Sun Ha Park - sunhapark@hanmail.net; Kyung Mee Kim - 96kmkim@hanmail.net; Won Kee Lee - wonlee@knu.ac.kr; Sin Kam - kamshin@knu.ac.kr; Sung Ick Cha - sicha@knu.ac.kr; Chang Ho Kim - kimch@knu.ac.kr; Young Mo Kang - ymkang@knu.ac.kr; Young-Chul Kim - kyc0923@chonnam.ac.kr; Sung Beom Han - sbhan@dsmc.or.kr; Tae Hoon Jung - thjung@knu.ac.kr; Jae Yong Park* - jaeyong@knu.ac.kr

* Corresponding author
\end{abstract}

Published: 24 October 2007

BMC Cancer 2007, 7:199 doi:10.1186/147/-2407-7-199
Received: 4 June 2007

Accepted: 24 October 2007

This article is available from: http://www.biomedcentral.com//47I-2407/7//99

(c) 2007 Choi et al; licensee BioMed Central Ltd.

This is an Open Access article distributed under the terms of the Creative Commons Attribution License (http://creativecommons.org/licenses/by/2.0), which permits unrestricted use, distribution, and reproduction in any medium, provided the original work is properly cited.

\begin{abstract}
Background: Polymorphisms in Epidermal Growth Factor Receptor (EGFR) gene may influence EGFR production and/or activity, thereby modulating susceptibility to lung cancer. To test this hypothesis, we investigated the association between polymorphisms in the EGFR gene and the risk of lung cancer in a Korean population.
\end{abstract}

Methods: We first examined the frequencies of 39 candidate polymorphisms in the EGFR gene in 27 healthy Korean individuals. After then, we genotyped five polymorphisms (I27378C>T, |42285G>A, 162093G >A, 181946C >T and 187||4T>C) that have variant allele frequencies greater than $10 \%$, in 582 lung cancer patients and in 582 healthy controls.

Results: Of the 5 polymorphisms, the 181946C $>$ T genotype distribution was significantly different between the cases and controls $(P=0.04)$. Compared with the $181946 C C+C T$ genotype, the 181946 TT genotype was associated with a significantly decreased risk of lung cancer (adjusted OR $=0.63,95 \% \mathrm{Cl}=0.45-0.88, P=0.007$ ). When the analyses were stratified by smoking status, the protective effect of the TT genotype was statistically significant in ever-smokers (adjusted OR = $0.59,95 \% \mathrm{Cl}=0.4 \mathrm{I}-0.86, P=0.007$ ), but not in never-smokers (adjusted $\mathrm{OR}=0.89,95 \% \mathrm{Cl}=$ $0.45-1.75, P=0.73 ; P=0.08$, test for homogeneity). Consistent with the results of the genotyping analysis, the CGGCT haplotype with the $181946 \mathrm{C}$ allele was associated with a significantly increased risk of lung cancer compared to the CGGTT haplotype carrying the 181946T allele (adjusted $\mathrm{OR}=1.50,95 \% \mathrm{Cl}=1.09-2.07, P=0.012$ and Bonferroni corrected $P$-value $=0.048$ ).

Conclusion: These results suggest that the EGFR polymorphisms, particularly the 181945C>T polymorphism, could be used as markers for the genetic susceptibility to lung cancer. 


\section{Background}

The development and progression of lung cancer is a multi-step process characterized by the accumulation of multiple genetic and epigenetic alterations, that results in perturbations of cell-regulatory and growth-control pathways $[1,2]$. The epidermal growth factor receptor (EGFR)driven pathway is known to be one of the known important oncogenic signang cascades in lung cancer [2-4].

The EGFR is a tyrosine kinase receptor that belongs to the ERBB family, and it mediates the intracellular effects of growth factors such as EGF, transforming growth factor $\alpha$ and neuregulins. The activation of EGFR via overexpression of the receptor and/or ligands or its structural alteration, affects a number of processes important to cancer development and progression, including cell proliferation, apoptosis, angiogenesis, and metastasis [5-7].

Single nucleotide polymorphisms (SNPs) are the most common sources of human genetic variation, and they may contribute to an individuals' susceptibility to cancer. Several studies have demonstrated that some variants affect either the expression or activities of various enzymes, and that they are therefore associated with the risk of cancer development [8-11]. Several polymorphisms in the EGFR gene have been reported [12-16] and deposited into public databases [17]. Although the functional effects of these polymorphisms have not yet been fully elucidated, we hypothesized that some of these variants may have an effect on EGFR expression or activity, and therefore may play a role in modulating the susceptibility to lung cancer. To test this hypothesis, we performed a case-control study to investigate the association between EGFR genotypes/haplotypes and the risk of lung cancer.

\section{Methods \\ Identification and selection of polymorphisms}

Among the candidate polymorphisms in the EGFR gene, we initially captured 39 SNPs in the promoter region, all exons including intron-exon boundaries (10 bp of the introns on either side) and the 3'-UTR of the gene because variants in these regions are most likely to affect gene function (Table 1). We then examined the frequencies of the captured SNPs in a preliminary study that included 27 healthy controls and 27 lung cancer cases. Among the 39 captured SNPs, seven SNPs [127378C >T (rs2072454), $142232 \mathrm{C}>\mathrm{T}$ (rs17336800), 142285G $>\mathrm{A}$ (rs11543848), $151904 \mathrm{~T}>\mathrm{A} \quad(\mathrm{rs} 17290169), 162093 \mathrm{G}>\mathrm{A} \quad(\mathrm{rs} 10251977)$, 181946C >T (rs2293347), and 187114T>C (rs884225)] had minor allele frequencies greater than $10 \%$ in the 54 subjects. The $142232 \mathrm{C}>\mathrm{T}$ and $151904 \mathrm{~T}>\mathrm{A}$ were completely or near completely linked with the $142285 \mathrm{G}>\mathrm{A}$. Thus five SNPs $(127378 \mathrm{C}>\mathrm{T}, 142285 \mathrm{G}>\mathrm{A}, 162093 \mathrm{G}>\mathrm{A}$, $181946 \mathrm{C}>\mathrm{T}$ and $187114 \mathrm{~T}>\mathrm{C}$ ) were chosen for the association study.

\section{Study population}

This case-control study included 582 lung cancer patients and 582 healthy controls (Table 2), and the details of the study population have been described previously $[18,19]$. In brief, the eligible cases included all patients who were newly diagnosed with primary lung cancer between January 2001 and June 2002 at Kyungpook National University Hospital, Daegu, Republic of Korea. There were no age, gender, histological, or stage restrictions, but patients with a prior history of cancer were excluded from the study. The cases included 270 (46.4\%) squamous cell carcinomas, 205 (35.2\%) adenocarcinomas, 97 (16.7\%) small cell carcinomas, and $10(1.7 \%)$ large cell carcinomas. The control subjects were randomly selected from a pool of healthy volunteers who visited the general health check-up center at Kyungpook National University Hospital during the same period. A total of 3065 (1598 males and 1467 females) of 5578 healthy subjects agreed to participate in this study (participation rate, 54.9\%). Compared with subjects that refused to participate, enrolled subjects showed similar sex (\% of male, $52.5 \%$ versus $52.1 \% ; P=0.80)$ and age $(52.2 \pm 11.4$ versus $52.1 \pm 11.3$; $P=0.80$ ) distributions. From 3065 healthy volunteers, we randomly selected 582 control subjects that were frequency-matched (1:1) to the cases based on sex and age ( \pm 5 years). All of the cases and the controls were ethnic Koreans and they resided in Daegu City or the surrounding regions. This study was approved by the institutional review board of the Kyungpook National University Hospital, and written informed consent was obtained from each participant.

\section{EGFR genotyping}

Genomic DNA was extracted from peripheral blood lymphocytes by proteinase $\mathrm{K}$ digestion and phenol/chloroform extraction. The EGFR $127378 \mathrm{C}>\mathrm{T}, 142285 \mathrm{G}>\mathrm{A}$ $(\mathrm{R} 521 \mathrm{~K}), 162093 \mathrm{G}>\mathrm{A}(\mathrm{N} 158 \mathrm{~N}), 181946 \mathrm{C}>\mathrm{T}(\mathrm{Q} 787 \mathrm{Q})$ and $187114 \mathrm{~T}>\mathrm{C}$ genotypes were determined using a PCRRFLP assay. PCR primers were designed based on the GenBank reference sequence (accession no. NT 033968). The PCR primers for $127378 \mathrm{C}>\mathrm{T}, 142285 \mathrm{G}>\mathrm{A}, 162093 \mathrm{G}>\mathrm{A}$, $181946 \mathrm{C}>\mathrm{T}$ and $187114 \mathrm{~T}>\mathrm{C}$ polymorphisms were $5^{\prime}-$ ATTGCGGGACTCTTGTTCGC-3' (forward) and 5'CGCCACTGGATGCTCTCCG (mutated A $\rightarrow$ G)C-3' (reverse); 5'-TCCCTGCTCTGTCACTGACT-3' (forward) and 5'-T AACAACAACCTGGAGCCTT-3' (reverse); 5'TGCCTCACCTCCACCGTGG (mutated $\mathrm{C} \rightarrow \mathrm{G}$ )A-3' (forward) and 5'-GCACGCACACACATATCCCC-3' (reverse); 5'-ATTGG CAAACACACAGGCAC-3' (forward) and 5'CTGCTGAAGAA GCCCTGCTG-3' (reverse); and 5'AGAAACGGAGGGGATGGAAT-3' and 5'-AGGTATTCCACATTCT CAGC-3' (reverse), respectively. PCR reactions were performed in a $20 \mu \mathrm{l}$ reaction volume containing 100 ng genomic DNA, $10 \mathrm{pM}$ of each primer, $0.2 \mathrm{mM}$ dNTPs, 10 mM Tris-HCl (pH 8.3), $50 \mathrm{mM} \mathrm{KCl}, 2.5 \mathrm{mM}$ 
Table I: Known and candidate polymorphisms in the EGFR gene

\begin{tabular}{|c|c|c|c|c|c|c|c|}
\hline \multirow[b]{2}{*}{ Region ${ }^{\dagger}$} & \multirow[b]{2}{*}{ Nucleotide (amino acid) change ${ }^{\dagger}$} & \multirow[b]{2}{*}{ SNP ID ${ }^{\dagger}$} & \multicolumn{5}{|c|}{ Variant allele frequency ${ }^{\dagger}$} \\
\hline & & & Korean (27 controls/27 cases) & Global & Caucasian & Asian & African American \\
\hline \multirow[t]{11}{*}{ Promoter } & $-\mid 433 C>T$ & rs 17335689 & $0.00 / 0.00$ & 0.017 & 0.00 & 0.00 & 0.042 \\
\hline & $-1298 G>A$ & rs 17335696 & $0.00 / 0.00$ & 0.006 & 0.00 & 0.00 & 0.042 \\
\hline & $-1247 G>A$ & rs6593197 & $0.00 / 0.00$ & - & 0.00 & 0.00 & 0.104 \\
\hline & $-1225 G>A$ & - & $0.00 / 0.00$ & - & 0.023 & 0.00 & 0.00 \\
\hline & $-759 C>A$ & rs75917I & $0.00 / 0.00$ & 0.101 & 0.136 & 0.00 & 0.146 \\
\hline & $-646 G>A$ & - & $0.00 / 0.00$ & - & 0.00 & 0.00 & 0.042 \\
\hline & $-6 \mid 5 C>G$ & rs 13228815 & $0.00 / 0.00$ & - & - & - & - \\
\hline & $-540 G>A$ & - & $0.02 / 0.00$ & - & 0.00 & 0.024 & 0.00 \\
\hline & $-482 C>A$ & rs 17335710 & $0.00 / 0.00$ & 0.006 & 0.00 & 0.00 & 0.063 \\
\hline & $-216 G>T$ & rs7|2829 & $0.02 / 0.04$ & 0.222 & 0.318 & 0.071 & 0.292 \\
\hline & $-191 C>A$ & rs7I2830 & $0.00 / 0.00$ & 0.078 & 0.136 & 0.00 & 0.00 \\
\hline \multirow[t]{2}{*}{ Intron I } & $169 \mathrm{G}>\mathrm{T}$ & rs 17335738 & $0.00 / 0.00$ & 0.101 & 0.114 & 0.00 & 0.114 \\
\hline & $2028 \mathrm{G}>\mathrm{A}$ & - & $0.07 / 0.07$ & - & 0.023 & 0.095 & 0.042 \\
\hline Exon 3 & I24080G>A (R98Q) & rs 17289589 & $0.00 / 0.00$ & 0.006 & - & - & - \\
\hline \multirow[t]{3}{*}{ Exon 4} & | 27378C>T (N I 58N) & rs 2072454 & $0.37 / 0.32$ & 0.415 & $0.500(0.42)^{\ddagger}$ & 0.320 & 0.457 \\
\hline & $|274| 7 C>T(D|7| D)$ & rs 17289686 & $0.00 / 0.00$ & 0.011 & - & - & - \\
\hline & I27435G>A (SI77S) & rs 17336437 & $0.00 / 0.00$ & 0.028 & - & - & - \\
\hline Intron 4 & I27473G>A IVS4+10) & rs7801956 & $0.00 / 0.02$ & 0.051 & 0.070 & 0.039 & 0.008 \\
\hline Exon 7 & $134783 C>G(P 266 R)^{\prime}$ & rs 17336639 & $0.00 / 0.00$ & 0.006 & - & - & - \\
\hline Exon 8 & I36584C>T (C307C) & rs 17289893 & $0.00 / 0.00$ & 0.011 & - & - & - \\
\hline Exon 9 & I37368G>A (P373P) & rs 2302536 & $0.00 / 0.00$ & 0.006 & 0.00 & 0.007 & - \\
\hline Exon 12 & I40880G>A (A439A) & rs 17290005 & $0.00 / 0.00$ & 0.022 & - & - & - \\
\hline \multirow[t]{2}{*}{ Exon 13} & I42232C>T (G503G) & rs 17336800 & $0.39 / 0.41$ & 0.006 & - & - & - \\
\hline & | 42285G>A (R52 I K) & rsII543848 & $0.39 / 0.41$ & 0.289 & $0.250(0.26)^{\ddagger}$ & 0.500 & 0.109 \\
\hline Exon 14 & | $44456 T>C(G 544 G)$ & rs 17290103 & $0.00 / 0.00$ & 0.022 & - & - & - \\
\hline \multirow[t]{4}{*}{ Exon 15} & I 46055T>C (V592A) & rs 28384375 & $0.00 / 0.00$ & - & - & - & - \\
\hline & 146068G >A (P596P) & rs 17290162 & $0.00 / 0.00$ & 0.017 & - & - & - \\
\hline & $|46| 19 \mathrm{C}>\mathrm{T}(\mathrm{A} 6 \mid 3 \mathrm{~A})$ & rs 17290169 & $0.00 / 0.00$ & 0.08 & $-(0.05)^{\ddagger}$ & - & - \\
\hline & $|46| 5 \mid G>T(C 624 F)$ & rs 28384376 & $0.00 / 0.00$ & - & - & - & - \\
\hline Exon 16 & I5I $1904 \mathrm{~T}>\mathrm{A}(\mathrm{T} 629 \mathrm{~T})$ & rs 17337023 & $0.37 / 0.41$ & 0.456 & $-(0.36)^{\ddagger}$ & $-(0.446) \S$ & - \\
\hline Exon 17 & I53806G>A (V674I) & rs 17337079 & $0.00 / 0.00$ & 0.006 & - & - & - \\
\hline Exon 18 & I54737G>T (G7|9C) & rs 28929495 & $0.00 / 0.00$ & - & - & - & - \\
\hline Exon 20 & I 62093G >A (Q787Q) & rs 10251977 & $0.07 / 0.13$ & 0.427 & $0.604(0.48)^{\ddagger}$ & 0.146 & 0.457 \\
\hline Exon 21 & I72480C >T (R836R) & rs 17518376 & $0.00 / 0.00$ & 0.011 & $0.083(0.07)^{\ddagger}$ & 0.00 & 0.00 \\
\hline Exon 23 & I79447T>C (T903T) & rsl|40475 & $0.07 / 0.06$ & 0.111 & $0.117(0.13)^{\ddagger}$ & 0.06 & 0.017 \\
\hline Exon 24 & $181074 C>G(R 962 G)$ & rs $1733745 \mid$ & $0.00 / 0.00$ & 0.06 & - & - & - \\
\hline \multirow[t]{2}{*}{ Exon 25} & I81927A>C (H988P) & rs 17290699 & $0.00 / 0.00$ & 0.006 & - & - & - \\
\hline & $181946 C>T$ (D994D) & rs 2293347 & $0.43 / 0.35$ & 0.197 & 0.136 & 0.286 & 0.053 \\
\hline 3'UTR & $|87| \mid 4 T>C$ & rs884225 & $0.37 / 0.31$ & 0.869 & 0.150 & 0.475 & 0.025 \\
\hline
\end{tabular}

† Information about SNPs, SNP ID and frequencies of variant alleles in other ethnic populations were obtained from NCBI database http:// www.ncbi.nlm.nih.gov. In the reference sequence (GenBank accession no. NT 033968), the translation start site was counted as +1 . In the cases of polymorphisms in the promoter and intron I (i.e., from - I433C>T to 2028G >A), frequencies of variant alleles in Caucasians, Asians and African Americans were obtained from Ref. 15.

‡Data in the parenthesis were obtained from Ref. 14.

$\S$ Datum in the parenthesis was obtained from Ref. 24.

$\mathrm{MgCl}_{2}, 5 \%$ DMSO and 1 unit of Taq polymerase (Takara Shuzo Co., Otsu, Shiga, Japan). The PCR cycle conditions consisted of an initial denaturation step at $95^{\circ} \mathrm{C}$ for $5 \mathrm{~min}$ followed by 35 cycles of $30 \mathrm{~s}$ at $94^{\circ} \mathrm{C} 30 \mathrm{~s}$ at $58^{\circ} \mathrm{C}$ for $127378 \mathrm{C}>\mathrm{T}$ and $187114 \mathrm{~T}>\mathrm{C}, 54^{\circ} \mathrm{C}$ for $142285 \mathrm{G}>\mathrm{A}$, $57^{\circ} \mathrm{C}$ for $162093 \mathrm{G}>\mathrm{A}$, and $56^{\circ} \mathrm{C}$ for $181946 \mathrm{C}>\mathrm{T}$; $30 \mathrm{~s}$ at $72^{\circ} \mathrm{C}$; and a final elongation at $72^{\circ} \mathrm{C}$ for $10 \mathrm{~min}$. The PCR products were digested overnight with the appropriate restriction enzymes (New England BioLabs, Beverly, MA,
USA) at $60^{\circ} \mathrm{C}(127378 \mathrm{C}>\mathrm{T})$ or $37^{\circ} \mathrm{C}(162093 \mathrm{G}>\mathrm{A}$, $142285 \mathrm{G}>\mathrm{A}, 181946 \mathrm{C}>\mathrm{T}$ and $187114 \mathrm{~T}>\mathrm{C})$. The restriction enzymes for $127378 \mathrm{C}>\mathrm{T}, 142285 \mathrm{G}>\mathrm{A}, 162093 \mathrm{G}>\mathrm{A}$, $181946 \mathrm{C}>\mathrm{T}$ and $187114 \mathrm{~T}>\mathrm{C}$ genotypes were $B s t U \mathrm{I}, \mathrm{BstNI}$, BanII, MlyI, and AciI, respectively. The digested PCR products were resolved on $6 \%$ acrylamide gel and stained with ethidium bromide for visualization under UV light. To ensure quality control, the genotyping analysis was performed "blind" with respect to case/control status. About 
Table 2: Characteristics of the study population

\begin{tabular}{lcc}
\hline Variable & Cases $(\mathrm{n}=582)$ & Controls $(\mathrm{n}=582)$ \\
\hline $\begin{array}{l}\text { Age (years) } \\
\text { Sex }\end{array}$ & $61.3 \pm 9.4$ & $60.2 \pm 9.6$ \\
$\quad$ Male & $467(80.2)^{\mathrm{a}}$ & $467(80.2)$ \\
$\quad$ Female & $115(19.8)$ & $115(19.8)$ \\
Smoking status & & \\
$\quad$ Current & $387(66.5)$ & $297(51.0)$ \\
$\quad$ Former & $85(14.6)$ & $147(25.3)$ \\
$\quad$ Never & $110(18.9)$ & $138(23.7)$ \\
Pack-yearsc & $40.0 \pm 17.7$ & $34.1 \pm 17.8$
\end{tabular}

a Numbers in parenthesis, percentage.

b $P<0.001$.

c In current and former smokers, $P<0.00$ I

$10 \%$ of the samples were randomly selected to be genotyped again by a different investigator, and the results were $100 \%$ concordant. Information about all SNPs, SNP ID and allele frequency was obtained from the NCBI homepage [17]. In the reference sequence, the translation start site was counted as +1 .

\section{Statistical analysis}

The cases and controls were compared using the Student's $t$-test for continuous variables and a $\chi^{2}$ test for categorical variables. Hardy-Weinberg equilibrium was tested using a goodness-of-fit $\chi^{2}$ test with one degree of freedom to compare observed genotype frequencies with expected genotype frequencies among the subjects. The strength of $\mathrm{LD}$ between pairs of polymorphisms was measured by HaploView [20]. The haplotypes and their frequencies were estimated based on a Bayesian algorithm using the Phase program [21]. Conditional logistic regression analysis was used to calculate odds ratios (ORs) and 95\% confidence intervals (CIs) for overall lung cancer, with adjustment of pack-years of smoking (as a continuous variable). In addition to the overall association analysis, we performed a stratified analysis by age (median age, $\leq 62$ years/>62 years), gender, smoking status, cigarette exposure level (median pack-years of smoking in ever-smokers, $\leq 38$ pack-years/>38 pack-years), and tumor histology to further explore the association between EGFR genotypes/ haplotypes and the risk of lung cancer in each stratum. The ORs and 95\% CIs in the stratification analyses were calculated using unconditional logistic regression analysis, with adjustment for gender, age or pack-years of smoking, when appropriate. The interaction between genotype and smoking was tested both with a logistic regression model that included the interaction term between genotype and smoking (pack-years of smoking or smoking exposure level), and by stratification analysis. The interaction term between genotype and smoking was not statistically significant, and this was removed from the logistic regression model. When multiple comparisons were made, the Bonferroni inequality method was used to calculate the corrected $P$-values (Pc-values) for multiple testing. All the analyses were performed using Statistical Analysis Software for Windows, version 8.12 (SAS institute, Gary, NC, USA).

\section{Results}

The genotype frequencies of the EGFR $127378 \mathrm{C}>\mathrm{T}$, $142285 \mathrm{G}>\mathrm{A}, 162093 \mathrm{G}>\mathrm{A}, 181946 \mathrm{C}>\mathrm{T}$ and $187114 \mathrm{~T}>\mathrm{C}$ polymorphisms among the cases and controls and their association with lung cancer risk are shown in Table 3. The genotype distributions of the $127378 \mathrm{C}>\mathrm{T}$, $142285 \mathrm{G}>\mathrm{A}, 162093 \mathrm{G}>\mathrm{A}, 181946 \mathrm{C}>\mathrm{T}$ and $187114 \mathrm{~T}>\mathrm{C}$ polymorphisms among the controls were in Hardy-Weinberg equilibrium $\left(\chi^{2}=0.004, P=0.95 ; \chi^{2}=0.98, P=0.32\right.$; $\chi^{2}=1.19, P=0.28 ; \chi^{2}=1.26, P=0.26$; and $\chi^{2}=0.15, P=$ 0.70 , respectively). The distribution of the $181946 \mathrm{C}>\mathrm{T}$ genotypes was significantly different between the cases and controls (CC, CT and TT genotypes; $41.6 \%, 46.1 \%$ and $12.4 \%$ vs $36.8 \%, 45.9 \%$ and $17.4 \% ; P=0.04$ ), with the frequency of the variant $\mathrm{T}$ allele being significantly lower in the cases than in the controls $(35.5 \%$ vs $40.4 \%$, $P=0.01)$. Compared with the 181946 CT + CC genotype, the 181946 TT genotype was associated with a significantly decreased risk of lung cancer (adjusted OR $=0.63$, $95 \% \mathrm{CI}=0.45-0.88, P=0.007)$. There was no significant difference in the genotype distributions of the other four polymorphisms studied between the cases and controls.

The association between the EGFR 181946C>T genotypes and the risk of lung cancer was further examined after stratification according to gender, age, smoking status, and histologic types of lung cancer. The effect of the TT genotype on the risk of lung cancer was similar in males and females, as well as in younger- and older-individuals (data not shown). When the analyses were stratified by smoking status, the protective effect of the TT genotype was statistically significant in ever-smokers (adjusted OR $=0.59,95 \% \mathrm{CI}=0.41-0.86, P=0.007$; Table 4 ) but not in never-smokers (adjusted OR $=0.89,95 \% \mathrm{CI}=0.45-$ $1.75, P=0.73 ; P=0.08$, test for homogeneity). Lung cancers are composed of heterogeneous histological types, and the pathways of carcinogenesis differ according to the histological types of lung cancer. Therefore, the effect of the EGFR $181946 \mathrm{C}>\mathrm{T}$ genotype on the risk of lung cancer was estimated according to the histological type of lung cancer. The protective effect of the TT genotype was pronounced in patients with small cell lung carcinoma and squamous cell carcinoma (adjusted $\mathrm{OR}=0.32,95 \% \mathrm{CI}=$ $0.14-0.73, P=0.007$; and adjusted $\mathrm{OR}=0.65,95 \% \mathrm{CI}=$ $0.41-1.01, P=0.06$, respectively).

We estimated the EGFR haplotypes of the $127378 \mathrm{C}>\mathrm{T}$, $142285 \mathrm{G}>\mathrm{A}, 162093 \mathrm{G}>\mathrm{A}, 181946 \mathrm{C}>\mathrm{T}$, and $187114 \mathrm{~T}>\mathrm{C}$ polymorphisms in the cases and controls, separately, and 
Table 3: EGFR genotypes of cases and controls, and their association with the risk of lung cancer

\begin{tabular}{|c|c|c|c|c|c|c|c|}
\hline \multirow[t]{2}{*}{ Genotypes } & \multicolumn{2}{|c|}{ Cases $(n=582)$, no. } & \multicolumn{2}{|c|}{ Controls $(n=582)$, no. } & \multirow[t]{2}{*}{$P \neq$} & \multirow[t]{2}{*}{ Crude OR $(95 \% \mathrm{Cl})$} & \multirow[t]{2}{*}{ Adjusted ORT (95\% Cl) } \\
\hline & $\mathrm{M} / \mathrm{F}^{\dagger}$ & Overall(\%) & $\mathrm{M} / \mathrm{F}^{\dagger}$ & Overall(\%) & & & \\
\hline \multicolumn{8}{|l|}{$127378 C>T$} \\
\hline $\mathrm{CC}$ & $194 / 59$ & $253(43.5)$ & $|96 / 6|$ & $257(44.2)$ & 0.61 & 1.00 & 1.00 \\
\hline CT & $208 / 45$ & $253(43.5)$ & $216 / 44$ & $260(44.7)$ & & $0.99(0.77-1.26)$ & $1.00(0.78-1.28)$ \\
\hline TT & $65 / 11$ & $76(13.1)$ & $55 / 10$ & $65(11.2)$ & & $1.19(0.82-1.73)$ & $1.22(0.83-1.78)$ \\
\hline T allele & & 0.348 & & 0.335 & 0.51 & & \\
\hline \multicolumn{8}{|l|}{ | $42285 G>A$} \\
\hline GG & $166 / 40$ & $206(35.4)$ & $161 / 54$ & $215(36.9)$ & 0.80 & 1.00 & 1.00 \\
\hline GA & $2|8 / 6|$ & 279 (47.9) & $224 / 44$ & $268(46.1)$ & & $1.09(0.84-1.40)$ & $1.11(0.86-1.44)$ \\
\hline AA & $83 / 14$ & $97(16.7)$ & $82 / 17$ & $99(17.0)$ & & $1.02(0.73-1.44)$ & $1.05(0.74-1.48)$ \\
\hline A allele & & 0.406 & & 0.400 & 0.77 & & \\
\hline \multicolumn{8}{|l|}{ I62093G $>A$} \\
\hline GG & $337 / 89$ & $426(73.2)$ & $343 / 86$ & $429(73.7)$ & 0.54 & 1.00 & 1.00 \\
\hline GA & $117 / 26$ & $143(24.6)$ & $117 / 28$ & 145 (24.9) & & $0.99(0.76-1.30)$ & $0.96(0.73-1.26)$ \\
\hline AA & $13 / 0$ & $13(2.2)$ & $7 / 1$ & $8(1.4)$ & & $1.64(0.67-3.99)$ & $1.60(0.65-3.97)$ \\
\hline A allele & & 0.145 & & 0.138 & 0.63 & & \\
\hline \multicolumn{8}{|l|}{$181946 C>T$} \\
\hline $\mathrm{CC}$ & $195 / 47$ & $242(4 \mid .6)$ & $181 / 33$ & $214(36.8)$ & 0.04 & 1.00 & 1.00 \\
\hline CT & $221 / 47$ & $268(46.1)$ & $212 / 55$ & $267(45.9)$ & & $0.89(0.69-1.14)$ & $0.89(0.69-1.15)$ \\
\hline TT & $5|/ 2|$ & $72(12.4)$ & $74 / 27$ & $101(17.4)$ & & $0.63(0.44-0.90)^{*}$ & $0.59(0.41-0.85)^{* *}$ \\
\hline $\mathrm{CC}+\mathrm{CT}$ & $416 / 94$ & $510(87.6)$ & $393 / 88$ & $481(82.6)$ & 0.02 & 1.00 & 1.00 \\
\hline TT & $51 / 21$ & $72(12.4)$ & $74 / 27$ & $101(17.4)$ & & $0.67(0.49-0.93)^{*}$ & $0.63(0.45-0.88) * * *, * * * *$ \\
\hline T allele & & 0.354 & & 0.403 & 0.01 & & \\
\hline \multicolumn{8}{|l|}{$|87| \mid 4 T>C$} \\
\hline TT & $162 / 42$ & $204(35.1)$ & $163 / 42$ & $205(35.2)$ & 0.78 & 1.00 & 1.00 \\
\hline TC & $215 / 54$ & $269(46.2)$ & $219 / 58$ & $277(47.6)$ & & $0.98(0.76-1.26)$ & $1.01(0.78-1.3 \mathrm{I})$ \\
\hline $\mathrm{CC}$ & $90 / 19$ & $109(18.7)$ & $90 / 15$ & $100(17.2)$ & & $1.10(0.79-1.53)$ & $1.16(0.83-1.63)$ \\
\hline C allele & & 0.418 & & 0.410 & 0.71 & & \\
\hline
\end{tabular}

† Male/Female.

$\ddagger$ Two-sided $\chi^{2}$ test for either genotype distributions or allele frequencies between the cases and controls.

I ORs $(95 \% \mathrm{Cls})$ were calculated by conditional logistic analysis, adjusted for pack-years of smoking.

$* P=0.01$.

*** $P=0.005$.

$* * * *=0.007$

**** $P=0.32$ for the interaction term between genotype and smoking status in the multivariate analysis.

Table 4: Stratification analysis of the EGFR I81946C $>$ T genotype frequencies in cases and controls

\begin{tabular}{|c|c|c|c|c|c|c|c|}
\hline \multirow[t]{3}{*}{ Variable } & \multicolumn{4}{|c|}{ Genotype, no (\%) } & & & \\
\hline & \multicolumn{2}{|c|}{ Cases } & \multicolumn{2}{|c|}{ Controls } & \multicolumn{3}{|c|}{ Adjusted OR (95\% Cl) } \\
\hline & $C C+C T$ & TT & $\mathrm{CC}+\mathrm{TT}$ & TT & $\mathrm{CC}+\mathrm{TT}$ & TT & $P$ \\
\hline \multicolumn{8}{|l|}{ Smoking status } \\
\hline Never & 91 (82.7) & $19(17.2)$ & $114(82.6)$ & $24(17.4)$ & 1.0 & $0.89(0.45-1.75)^{\dagger}$ & 0.73 \\
\hline Ever $\ddagger$ & $419(88.8)$ & $53(11.2)$ & $367(82.7)$ & $77(17.3)$ & 1.0 & $0.59(0.4 \mathrm{I}-0.86)^{\dagger}, *$ & 0.007 \\
\hline$\leq 38$ pys & $168(88.4)$ & $22(11.6)$ & $226(84.0)$ & $43(16.0)$ & 1.0 & $0.64(0.37-1.12)^{\dagger}$ & 0.12 \\
\hline$>38$ pys & $251(89.0)$ & $31(11.0)$ & $14 \mid(80.6)$ & $34(19.4)$ & 1.0 & $0.52(0.30-0.88)^{\dagger}$ & 0.01 \\
\hline \multicolumn{8}{|l|}{ Histologic types§ } \\
\hline Squamous cell ca. & $238(88.1)$ & 32 (11.9) & $48 \mid(82.6)$ & $101(17.4)$ & 1.0 & $0.65(0.4 \mathrm{I}-\mathrm{I} .0 \mathrm{I})^{\pi}$ & \\
\hline Adenoca. & $173(84.4)$ & $32(15.6)$ & $481(82.6)$ & $101(17.4)$ & 1.0 & $0.82(0.52-1.28)^{\pi}$ & \\
\hline Small cell ca. & $90(92.8)$ & 7 (7.2) & $481(82.6)$ & $101(17.4)$ & 1.0 & $0.32(0.14-0.73)^{\pi}$ & \\
\hline
\end{tabular}

† Adjusted for age and pack-years of smoking.

‡ Current and former smoker.

$\S$ Ten large cell carcinoma cases were excluded from this analysis.

Tा Adjusted for gender and pack-years of smoking.

$* P=0.08$, test for homogeneity test between genotype-related ORs of never- and ever-smokers. 


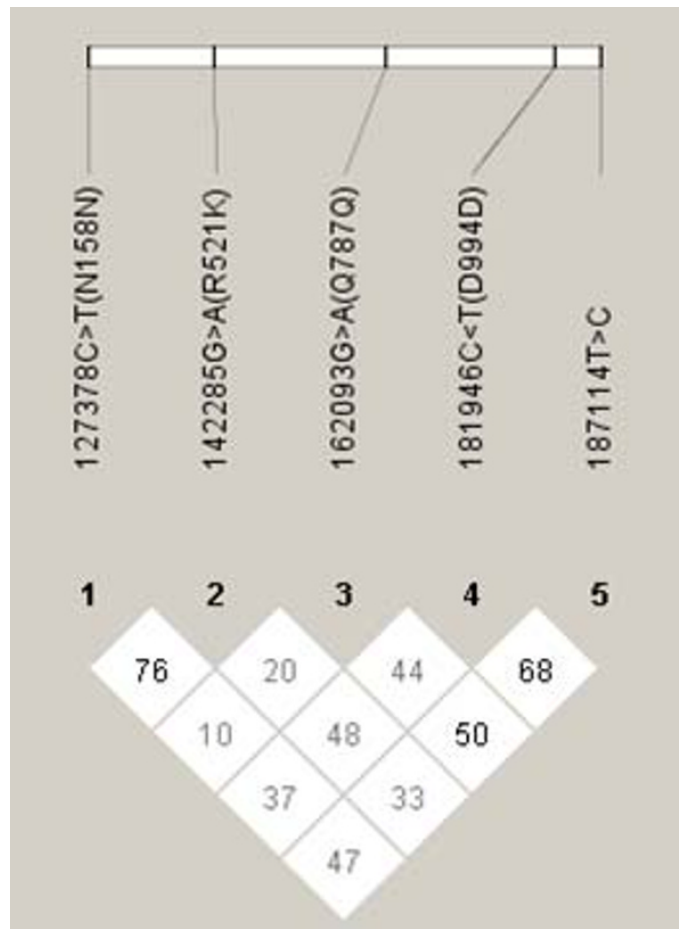

Figure I

Linkage disequilibrium values $\left|D^{\prime}\right|(\times 100)$ between EGFR polymorphisms among 582 healthy Koreans.

we compared their frequency distributions between the cases and controls. The five polymorphisms were not in strong LD (Fig. 1), and thus established 29 out of the 32 $\left(2^{5}\right)$ potential haplotypes. The 25 haplotypes that had a frequency of less than $5 \%$ were pooled into a single group and included in the haplotype analysis. Table 5 shows the inferred haplotype distribution for the controls and cases, and the lung cancer risk related to each haplotype. Because the 181946TT genotype had a significant protective effect against lung cancer in the logistic regression analysis for each polymorphism, the adjusted ORs and 95\% CIs were calculated using the CGGTT haplotype with the 181946T allele as the reference group. Compared to the CGGTT haplotype, the CGGCT haplotype, which is one of three haplotypes carrying the $181946 \mathrm{C}$ allele, was associated with a significantly increased risk of lung cancer (adjusted $\mathrm{OR}=1.50,95 \% \mathrm{CI}=1.09-2.07, P=0.012$, $P c=0.048)$.

\section{Discussion}

DNA sequence variations in the EGFR gene may lead to alteration in the production and/or activity of the EGFR, thereby causing interindividual differences in lung cancer susceptibility. To test this hypothesis, we evaluated the potential association of five EGFR polymorphisms $(127378 \mathrm{C}>\mathrm{T}, 142285 \mathrm{G}>\mathrm{A}, 162093 \mathrm{G}>\mathrm{A}, 181946 \mathrm{C}>\mathrm{T}$ and $187114 \mathrm{~T}>\mathrm{C}$ ) and the risk of lung cancer. In addition, the EGFR haplotypes composed of five polymorphisms were estimated, and their frequency distributions in the lung cancer cases and controls were compared. Of the five polymorphisms studied, the $181946 \mathrm{C}>\mathrm{T}$ polymorphism was associated with a significantly decreased risk of lung cancer. This finding suggests that this polymorphism might be a useful marker for determining genetic susceptibility to lung cancer.

When studying polymorphisms using a limited number of subjects, low minor allele frequencies of the polymorphism may lead to null result although the polymorphism is meaningful for the risk of target disease [22-24]. In order to identify common variants (frequencies above $10 \%)$, we first determined the frequencies of the 39 reported polymorphisms in a preliminary study that included 27 healthy Koreans and 27 lung cancer cases. In the present study, we validated the presence of 11 polymorphisms in a Korean population: $-540 \mathrm{G}>\mathrm{A},-216 \mathrm{G}>\mathrm{T}$, $2028 \mathrm{G}>\mathrm{A}, \quad 127378 \mathrm{C}>\mathrm{T}, \quad 142232 \mathrm{C}>\mathrm{T}, \quad 142285 \mathrm{G}>\mathrm{A}$, $151904 \mathrm{~T}>\mathrm{A}, 162093 \mathrm{G}>\mathrm{A}, 179447 \mathrm{~T}>\mathrm{C}, 181946 \mathrm{C}>\mathrm{T}$ and $187114 \mathrm{~T}>\mathrm{C}$. However, the other 28 candidate polymor-

Table 5: EGFR haplotype frequencies in the cases and controls, and their association with lung cancer risk

\begin{tabular}{|c|c|c|c|c|}
\hline \multirow[t]{2}{*}{ Haplotype ${ }^{\dagger}$} & \multirow{2}{*}{$\begin{array}{c}\text { Controls }(\mathrm{n}=1 \mathrm{I} 64) \\
\text { no. }(\%)\end{array}$} & \multicolumn{3}{|c|}{ Cases $(n=1164)$} \\
\hline & & no. (\%) & Adjusted§ OR $(95 \% \mathrm{Cl})$ & $P$ \\
\hline CGGCT & 91 (7.8) & $118(10.1)$ & $1.50(1.09-2.07)$ & $0.012^{*}$ \\
\hline CGGCC & $124(10.7)$ & $110(9.5)$ & $1.08(0.80-1.47)$ & 0.60 \\
\hline CGGTT & $350(30.1)$ & $305(26.2)$ & 1.00 & \\
\hline TAGCC & $227(19.5)$ & $234(20.1)$ & $1.24(0.97-1.58)$ & 0.09 \\
\hline Others $\ddagger$ & $372(32.0)$ & $397(34.1)$ & $1.24(0.98-1.54)$ & 0.07 \\
\hline Global $P$ & & 0.08 & & \\
\hline
\end{tabular}

†The order of polymorphisms is as follows: $|17378 \mathrm{C}>\mathrm{T}| ,42285 \mathrm{G}>\mathrm{A},|62093 \mathrm{G}>\mathrm{A}| 8 \mid, 946 \mathrm{C}>\mathrm{T}$ and |87||4T>C.

$¥$ Twenty-five haplotypes that had a frequency of less than $5 \%$.

$\S$ Adjusted for age, gender and pack-years of smoking.

* Bonferroni corrected $P$-value $=0.048$. 
phisms listed in Table 1 were not detected in the preliminary study. Considering the sample size of the study, the $127378 \mathrm{C}>\mathrm{T}, 142232 \mathrm{C}>\mathrm{T}, 162093 \mathrm{G}>\mathrm{A}, 181946 \mathrm{C}>\mathrm{T}$ and $187114 \mathrm{~T}>\mathrm{C}$ that have variant allele frequencies $>10 \%$ were subjected to a case-control study to examine their association with lung cancer risk.

A few studies have investigated the association between EGFR polymorphisms and the risk of human cancer [2527]. A (CA $)_{n}$ dinucleotide repeat polymorphism in intron 1 of the EGFR gene has been shown to affect the basal transcription activity of the EGFR gene; subjects with short CA repeats have been shown to have increased EGFR expression [28,29]. Moreover, Kang et al. [25] reported that Puerto Rican subjects having a lower number of CA repeats showed an increased risk of oral cancer. In contrast, we found that this dinucleotide polymorphism does not significantly contribute to the genetic susceptibility to lung cancer in Koreans [26], and we therefore excluded this polymorphism from the current study. In addition to the $(\mathrm{CA})_{\mathrm{n}}$ repeat polymorphism, the $-216 \mathrm{G}>\mathrm{T}$ polymorphism, located in a Sp1 recognition site of the EGFR promoter, has been shown to increase the promoter activity by $30 \%$ [15]. This polymorphism has also been associated with an increased risk of glioblastoma in a European Caucasian population [27]. Despite its functional significance, the $-216 \mathrm{G}>\mathrm{T}$ polymorphism was not included in an association analysis in the present study because the frequency of the $-216 \mathrm{G}>\mathrm{T}$ polymorphism was rare $(1.9 \%)$ among the 27 healthy Koreans in the preliminary study. Therefore, additional studies with larger sample sizes are needed to determine the effect of the $-216 \mathrm{G}>\mathrm{T}$ polymorphism on the risk of lung cancer in a Korean population.

A nonsynonymous $142285 \mathrm{G}>\mathrm{A}$ (R521K) polymorphism, located in the extracellular ligand-binding domain of the EGFR gene has been shown to decrease ligand binding affinity, thus attenuating growth stimulation, tyrosine kinase activation and the induction of protooncogenes such as FOS, JUN, and MYC [13]. In the present study, however, this nonsynonymous polymorphism was not associated with the risk of lung cancer. The frequency of the variant $521 \mathrm{~K}$ allele reported in the NIH database [17] shows remarkable variation between different ethnic groups ( 0.109 of African Americans, 0.250 of Caucasians, and 0.500 of Asians). Therefore, further studies are needed to clarify the association between the $\mathrm{R} 521 \mathrm{~K}$ polymorphism and lung cancer in different ethnic populations.

In the present study, individuals carrying the 181946 TT genotype were at a significantly decreased risk of lung cancer in comparison to those individuals with the 181946 CT or CC genotype. The mechanism underlying the association between the $181946 \mathrm{C}>\mathrm{T}$ polymorphism and lung cancer risk remains to be elucidated. Because the $181946 \mathrm{C}>\mathrm{T}$ polymorphism does not result in an amino acid change, nor does it reside within the functional domain, the observed effect of the $181946 \mathrm{C}>\mathrm{T}$ polymorphism on lung cancer may be due to LD with other functional EGFR variant(s) that were not tested in this study. Therefore, additional studies are needed to detect the other functional variants in the EGFR gene and their associations with lung cancer.

Another interesting finding of this study was an interaction between the EGFR polymorphism and tobacco smoking. The EGFR 181946C $>\mathrm{T}$ polymorphism was significantly associated with the risk of lung cancer in the smokers but not in the never-smokers, which reflects a gene-environment interaction. However, because the interaction term between the genotype and smoking was not statistically significant in the multivariate logistic regression analysis $(P=0.32$ for the interaction term), the failure to observe a significant effect in never-smokers might be due to the relatively small number of subjects in this group. Therefore, additional studies must be conducted with a greater number of subjects in order to confirm these findings.

Recent studies have demonstrated that the haplotype has greater power to detect disease associations than an individual polymorphism on account of LD with the diseasecausative variants. In addition, haplotype analysis offers the advantages of not assuming that any of the genotyped polymorphisms are functional, and it allows for the possibility of an ungenotyped functional variant to be in LD with the genotyped polymorphisms [30-32]. Therefore, our investigation was extended to analyze the EGFR haplotypes composed of the $127378 \mathrm{C}>\mathrm{T}, 142285 \mathrm{G}>\mathrm{A}$, $162093 \mathrm{G}>\mathrm{A}, 181946 \mathrm{C}>\mathrm{T}$ and $187114 \mathrm{~T}>\mathrm{C}$ polymorphisms. In the haplotype analysis, only one (the CGGCT haplotype) of the three haplotypes carrying the 181946C allele was associated with a significantly increased risk of lung cancer in comparison to the CGGTT haplotype with the $181946 \mathrm{~T}$ allele. These results also suggest that haplotype analysis may be a more suitable tool for assessing the disease-association than the individual polymorphism. However, the result of this haplotype analysis should be interpreted with caution due to a limitation of the computational methods used for haplotype estimation. The computational methods can be used to effectively and accurately predict haplotypes in genetic regions with pronounced LD but not in regions where marked LD is not maintained [33,34]. Therefore, since the five EGFR polymorphisms studied were not in strong $\mathrm{LD}$, it is possible that there may have been an estimation error in the EGFR haplotype estimation. In addition, because this study was designed to evaluate the effects of EGFR polymorphisms on the risk of overall lung cancer, the stratification analy- 
ses according to age, gender, smoking status and tumor histology might have a type I error (due to multiple comparisons) and/or a type II error (due to the small number of subjects in the subgroups). Therefore, additional studies with larger sample sizes are required to confirm our findings.

\section{Conclusion}

In this study, we tested the hypothesis that polymorphisms in the EGFR gene can affect the risk of lung cancer in the general population. We found that the $181946 \mathrm{C}>\mathrm{T}$ polymorphism was associated with the risk of lung cancer. This result suggests that the EGFR 181946C>T polymorphism could be used as a marker for the genetic susceptibility to lung cancer; however, additional studies with larger sample sizes are needed to confirm our findings. Future studies on the other EGFR sequence variants and their biological function are also needed in order to understand the role of the $181946 \mathrm{C}>\mathrm{T}$ polymorphism in determining the risk of lung cancer. Moreover, because genetic polymorphisms often vary between different ethnic groups, further studies are needed to clarify the association of the EGFR polymorphisms with the risk of lung cancer in diverse ethnic populations.

\section{Abbreviations used}

EGFR, epidermal growth factor receptor; SNP, single nucleotide polymorphisms; LD, linkage disequilibrium; $\mathrm{OR}$, odds ratio; $\mathrm{CI}$, confidence interval; $P c$-value, Bonferroni corrected $P$-value.

\section{Competing interests}

The author(s) declare that they have no competing interests.

\section{Authors' contributions}

JEC, SHP and KMK participated in the design of study, and carried out sequencing and genotyping, and participated in statistical analysis and interpretation of data. WKL and SK participated in the design of study, and analysis and interpretation of data. SIC, CHK, THJ participated in the design of study and collected clinical data. YMK, YCK and SBH participated in the design of study and helped to draft the manuscript. JYP conceived the study and participated in the design of study, analysis and interpretation of data, drafting the article and final approval of this version. All authors read and approved the final manuscript.

\section{Acknowledgements}

This study is supported in part by a grant from the national R\&D Program for Cancer Control Ministry of Health \& Welfare, Republic of Korea (0720550-2), and in part by the Brain Korea 2I Project in 2006

\section{References}

I. Ponder BA: Cancer genetics. Nature 200 I, 4I I:336-34I.
2. Sekido Y, Fong KM, Minna JD: Molecular genetics of lung cancer. Ann Rev Med 2003, 54:73-87.

3. Gazdar AF, Shigematsu H, Herz J, Minna JD: Mutations and addiction to EGFR: the Achilles 'heal' of lung cancers? Trends $\mathrm{Mol}$ Med 2004, 10:481-486.

4. Mao L: Recent advances in the molecular diagnosis of lung cancer. Oncogene 2002, 2 1:6960-6969.

5. Yarden Y, Sliwkowski MX: Untangling the ErbB signaling network. Nat Rev Mol Cell Biol 200I, 2:I27-I37.

6. Arteaga $C L$ : Overview of epidermal growth factor receptor biology and its role as therapeutic target in human neoplasia. Semin Oncol 2002, 29:3-9.

7. Jorissen RN, Walker F, Pouliot N, Garrett TP, Ward CW, Burgess AW: Epidermal growth factor receptor: mechanisms of activation and signaling. Exp Cell Res 2003, 284:3I-53.

8. Sun T, Miao X, Zhang X, Tan W, Xiong P, Lin D: Polymorphisms of death pathway genes FAS and FASL in esophageal squamous-cell carcinoma. J Natl Cancer Inst 2004, 96:1030-I036.

9. Jang JS, Lee SJ, Choi JE, et al.: Methyl-CPG binding domain I gene polymorphisms and risk of primary lung cacner. Cancer Epidemiol Biomark Prev 2005, I 4:2474-80.

10. Zhang X, Miao X, Guo Y, et al.: Genetic polymorphisms in cell cycle regulatory genes MDM2 and TP53 are associated with susceptibility to lung cancer. Hum Mutat 2006, 27: I I0-7.

I I. Park JY, Park JM, Jang JS, Choi JE, Kim KM, Cha SI, Kim CH, Kang YM, Lee WK, Kam S, Park RW, Kim IS, Lee JT, Park JY: Caspase 9 promoter polymorphisms and risk of primary lung cancer. Hum Mol Genet 2006, I5:1963-1971.

12. Chrysogelos SA: Chromatin structure of the EGFR gene suggests a role for intron I sequences in its regulation in breast cancer cells. Nucleic Acids Res 1993, 2 I:5736-574I.

13. Morial T, Kobrin MS, Hope C, Speck L, Korc M: A variant epidermal growth factor receptor exhibits altered type alpha transforming growth factor binding and transmembrane signaling. Proc Natl Acad Sci USA 1994, 91 : I 02 I7- I0221.

14. Frederick $L$, Wang $X Y$, Eley $G$, James $C D$ : Diversity and frequency of epidermal growth factor receptor mutations in human glioblastoma. Cancer Res 2000, 60: I383-1387.

15. Liu W, Innocenti F, Wu MH, Desai AA, Dolan ME, Cook EH Jr, Ratain $\mathrm{MJ}$ : A functional common polymorphism in a Sp I recognition site of the epidermal growth factor receptor gene promoter. Cancer Res 2005, 65:46-53.

16. Hsieh YY, Chang CC, Tsai FJ, Lin CC, Tsai CH: T homozygote and allele of epidermal growth factor receptor 2073 gene polymorphism are associated with higher susceptibility to endometriosis and leiomyomas. Fertility Sterility 2005, 83:796-799.

17. [http://www.ncbi.nlm.nih.gov/SNP].

18. Park SH, Choi JE, Kim EJ, Jang JS, Lee WK, Cha SI, Kim CH, Kam S, Kim DS, Park RW, Kim YC, Han SB, Jung TH, Park JY: Polymorphisms in the FAS and FASL genes and risk of lung cancer in a Korean population. Lung Cancer 2006, 54:303-308.

19. Jun HJ, Park SH, Lee WK, Choi JE, Jang JS, Kim EJ, Cha SI, Kim DS, Kam S, Kim CH, Kang YM, Jung TH, Park JY: Combined effects of p73 and MDM2 polymorphisms on the risk of lung cancer. Mol Carcinog 2007, 46:100-105.

20. [http://www.broad.mit.edu/mpg/haploview].

21. Stephens M, Smith MJ, Donnelly P: A new statistical method for haplotype reconstruction from population data. Am J Hum Genet 200I, 68:978-989.

22. Risch NJ: Searching for genetic determinants in the new millennium. Nature 2000, 405:847-856.

23. Brennan P: Gene-environment interaction and aetiology of cancer: what does it mean and how cancer we measure it? Carcinog 2002, 23:381-387.

24. Becker N, Nieters A, Rittgen W: Single nucleotide polymorphism-disease relationship: statistical issues for the performance of association studies. Mut Res 2003, 525: I I-18.

25. Kang D, Gridley G, Huang WY, Engel LS, Winn DM, Brown LM, Bravo-Otero E, Wu T, Diehl SR, Hayes RB: Microsatellite polymorphisms in the epidermal growth factor receptor (EGFR) gene and the transforming growth factor- (TGFA) gene and risk of oral cancer in Puerto Rico. Pharmacogenet Genomics 2005, I 5:343-347.

26. Lee SJ, Kim KM, Chae MH, Lee WK, Kam S, Cha SI, Han HS, Kim CH, Kang YM, Han SB, Park JY: No association between dinucleotide 
repeats polymorphism in intron I of the epidermal growth factor receptor gene EGFR and risk of lung cancer. Cancer Genet Cytogenet 2007, 172:29-32.

27. Carpentier C, Laigle-Donadey F, Marie Y, Auger N, Benouaich-Amiel A, Lejeune J, Kaloshi G, Delattre JY, Thillet J, Sanson M: Polymorphism in SpI recognition site of the EGF receptor gene promoter and risk of glioblastoma. Neurology 2006, 67:872-874.

28. Gebhard F, Zanker KS, Brandt B: Modulation of epidermal growth factor receptor gene transcription by a polymorphic dinucleotide repeat in intron I. J Biol Chem 1999, 274:13 I76-13180.

29. Amador ML, Oppenheimer D, Perea S, Maitra A, Cusati G, lacobuzioonahue C, Baker SD, Ashfaq R, Takimoto C, Forastiere A, Hidalgo M: An epidermal growth factor receptor intron I polymorphism mediates response to epidermal growth factor receptor inhibitor. Cancer Res 2004, 64:9139-9/43.

30. Bader JS: The relative power of SNPs and haplotypes as genetic markers for association tests. Pharmaocogenomics 200 I, 2:II-24.

31. Judson R, Stephens JC, Windemuth A: The predictive power of haplotypes in clinical response. Pharmacogenomics 2000, I:I5-26.

32. Judson R, Stephens JC: Notes from the SNP vs. haplotype front. Pharmacogenomics 200I, 2:7-10.

33. Hoh J, Hodge S: A measure of phase ambiguity in pairs of SNPs in the presence of linkage disequilibrium. Hum Hered 2000, 50:359-364.

34. Xu CF, Lewis K, Cantone KL, Khan P, Donnelly C, White N, Crocker N, Boyd PR, Zaykin DV, Purvis IJ: Effectiveness of computational methods in haplotype estimation. Hum Genet 2002, I 10:148-156.

\section{Pre-publication history}

The pre-publication history for this paper can be accessed here:

http://www.biomedcentral.com/1471-2407/7/199/pre

pub

Publish with Biomed Central and every scientist can read your work free of charge

"BioMed Central will be the most significant development for disseminating the results of biomedical research in our lifetime. "

Sir Paul Nurse, Cancer Research UK

Your research papers will be:

- available free of charge to the entire biomedical community

- peer reviewed and published immediately upon acceptance

- cited in PubMed and archived on PubMed Central

- yours - you keep the copyright 